the New York Times to call the Holy See a "degrading influence."

For the first time there will be official observers from outside the Roman Catholic Church (as there were, for the first time, official Catholic observers at the Third Assembly of the World Coumcil of Churches in New Delhi). And not only Christians, but others, believers and nonbelievers, will watch to see how the Church pronounces on such essential matters as religious liberty, relations of Church and State, or the role of the laity. If the Council proceeds in the spirit of John XXIII it will emphasize things that unite rather than things that divide. If it does, and meets the response it can properly expect, then not only the Catholic Church, but all men who share an ultimate concern for human dignity and international peace, will be able to front the future with greater strength and effectiveness and a realistic hope for a more ordered world. Amid all, in the modern world, that tends to sunder and shatter relations between men, the Council may serve to recall men to their essential unity.

\section{CUBA, PAST AND PRESENT}

Cuba has been a burr under the saddle of our foreign policy for some years now. As a result, our attitudes toward the regimes of both Batista and Castro, under the administrations of both Eisenhower and Kennedy have been jumpy and erratic. When pressed to act we have: we finally withdrew support from Batista and he was overthrown; we supported an invasion of Castro's Cuba and he was not overthrown. Between such moments, we have had time to recoup and formulate a sound policy. With the unerring accuracy of hindsight, it is easy to say that we have failed to make the best use of these quiescent periods.

Now, as the Communist buildup increases, as more men and arms are shipped in from Russia, irritation increases, another crisis seems clearly in the making, and the call for some quick, decisive action grows louder. While many Americans criticize the limited actions our government has taken, precisely because they are limited, America's allies seem to be critical of our government because it has acted at all. What one views as apathy and lethargy the other sees as nearhysteria.

At this point it is unlikely-and it would certain ly be foolish-that the administration will follow the course recommended by either of these two significant and vocal groups, one within and the other outside our country. A full-scale blockade or an invasion of the island, which is one recommendation, could succeed in replacing Castro. But the price would be exorbitant-to us, to our allies, and to our negotiations and maneuvers in various other parts of the world, not least of all Berlin. But it would be equally foolish-and, fortunately, it is just as unlikely-to act as if Castro's Cuba does not present a real problem. It may not pose a significant military threat and it is hardly a showcase for Communism, but it is a Communist base in our hemisphere. If our allies do not see it as a problem, we must shoulder the burden alone.

It is frequently pointed out that Cuba is only ninety miles off the coast of the United States. The reverse is also true, and it allows us a freedom of action that no other country has in relation to Cuba: We could readily launch vast military forces if conditions called for it. Our task now is to see that such conditions do not arise, that Cuba does not become the Communist showcase it was intended to be, that an effective cam. paign of subversion does not fan out from that island to other countries in the hemisphere. What is demanded is neither apathy nor hysteria, but simply the application of knowledge and ability we can be expected to possess.

\title{
in the magarines
}

The Spring 1962 issue of Cfoss Currents, devoted entirely to the Second Vatican Council, constitutes a dialogue between Catholic, Orthodox, Anglican and Protestant Christians, both priests and laymen. They present their expectations for the outcome of the deliberations in Rome and what reforms, re- newals or innovations they wish to see discussed and acted upon. Articles from France, Germany, Spain, Italy and Poland (results of a symposium begun by the French monthly, Esprit) are included in the volume, as well as a number front the U.S. A view of the Council by Asian and African lay.

2: worldvieto 